\title{
The Political Economy Perspective of Forest Governance Responding REDD+ in Indonesia
}

\author{
Pungky Widiaryanto ${ }^{1}$ \\ Ministry of National Development Planning (Bappenas)
}

Corresponding author. Email: pungky.widiaryanto@bappenas.go.id

Submitted: August $10^{\text {th }} 2020$ | Accepted: September $21^{\text {st }} 2020$ | Published: September $28^{\text {th }} 2020$

\begin{abstract}
Reducing Emissions from Deforestation and Forest Degradation (REDD+) has become important for Indonesia because this mechanism will provide financial benefits, whereas it adheres to the Indonesian commitment to participate in climate change mitigation. However, a weak forest governance system and lack of transparency have undermined Indonesia's goals to reduce deforestation and to manage and distribute the compensation appropriately. The idea of transformational change to reform Indonesian forest governance might be hindered by path dependency that has become entrenched within the Indonesian government. This paper, therefore, attempts to analyze the path dependency of Indonesian forest governance and to examine the implication of path dependency in the development of REDD+ in Indonesia. Using the political economy lens, the diagnosis of the path dependency is determined if there are positive feedbacks for the Ministry of Forestry, as the leading agency in the administration of Indonesian forests, to maintain the status quo. This paper shows that there are four positive or reinforcing feedbacks for the Ministry of Forestry: (1) vested interests for utilizing the forests as an income source, (2) network effects from managing the forest resources, (3) sunk costs invested to strengthen the institution, and (4) inclusiveness of the institution in managing the forests. This paper also highlights that path dependency within the Ministry of Forestry causes complexity in the REDD+ debate in Indonesia, particularly regarding which institutional arrangement will best implement REDD+. On the other hand, this paper shows that various policies and activities related to REDD+ could break path dependency.
\end{abstract}

Keywords: REDD+, transformational change, path dependency

${ }^{1}$ Pungky Widiaryanto is a planning staff member at Directorate of Forestry and Water Resources Conservation, Ministry of National Development Planning (Bappenas), Jakarta, Indonesia. 


\title{
The Political Economy Perspective of Forest Governance Responding REDD+ in Indonesia
}

\author{
Pungky Widiaryanto
}

\section{Introduction}

1.1 Background and problem statement

Most recent research indicates that emissions from deforestation and land use change have generated net carbon emissions at a rate of $1.4 \mathrm{PgC}$ per year globally during the 19902010 period (Houghton, 2012). This large amount has made reducing emissions from those sectors a priority. The international community is currently negotiating a future mechanism to mitigate climate change by reducing emission from deforestation and forest degradation including the role of forests in sequestering significant amount of carbon in the atmosphere; the United Nations program is known as Reducing Emissions from Deforestation and Forest Degradation Plus (REDD+). The Kyoto Protocol, the current international legally binding policy under the United Nations Framework Convention on Climate Change (UNFCCC), expired in 2012 and is extended until 2020. It remains in a contentious political debate among countries. The REDD+ mechanism may lead to a promising new legal treaty. Originally, the idea of REDD+ was to compensate developing countries that could reduce their emission from forest and land use-based sectors in order to participate in slowing down climate change.

For almost ten years, many actors such as negotiators, stakeholders and researchers have debated the notion of REDD+. In the beginning of negotiations, the complexity in developing this mechanism was central to political dialogue between northern countries, which are dominated by industrialized countries, and southern countries, that are associated with the developing world. Discussions were dominated by technical issues such as how to measure, report and verify the emissions (MRV), and how to deal with the issues of additionality, leakage and permanence (Pistorius, 2012). At the same time, activists from non-government organizations (NGOs) and civil society organizations (CSOs) also proposed that REDD+ should include the importance of co-benefits for other environment objectives such as biodiversity conservation, and for livelihoods particularly for local communities living in and near the forests (Pistorius, 2012). Pistorus (2012) also highlighted that the most recent evolution of REDD+ is about the capacity of most developing countries in curbing deforestation. Effective efforts to address deforestation encompass a long history of a developing country and the complexity of the political and economic context.

Moreover, Murdiyarso and others (2012) assessed the first generation of REDD+ demonstration activities around the world, and found that the central debate surrounding REDD+ comprises a trade-off between protecting forests and increasing economic development goals. Development is a driver of deforestation; deforestation is exacerbated by expanding agricultural plantations, and by weak of governance systems in developing nations. The authors suggested that the success of REDD+ requires a transformational change in the forest governance system; even though the reform process must deal with country's economic interest and political power (Murdiyarso et al., 2012). The uncertainty of political and economic conditions in most developing nations has undermined the 
industrialized countries ability to transfer such funds for implementing REDD+. On the other hand, many developing world countries argue that the new additional funding can be mobilized to support attempts to reduce deforestation by transforming such policies related to forest and land-based sector. However, imposing a transformational change to reduce deforestation in developing countries turns out much more difficult than previous discourses on technical issues.

Indonesia, a forested developing country in the tropics, would benefit from REDD+ funding. However, the weak governance system has undermined Indonesia in tackling deforestation. Indonesia currently must deal with reform in forest governance in order to implement REDD+. Current macroeconomic factors have led Indonesia to expand oil palm plantations and other land-based activities that become main drivers of deforestation in Indonesia. On the other hand, various studies also indicate that the deforestation in Indonesia is not only driven by economic targets, but it also caused by poor forest governance system and lack of transparent financial management (Barr et al., 2010; McCarthy, 2000). The reform process in Indonesia, particularly in forest governance, must deal with oligarchies rule that has been entrenched and persists in political relationships (Ash Institute for Democratic Governance and Innovation, 2011). This rule has become the prevailing culture within the Indonesian bureaucracy, and may hinder the necessary transformational change in forest governance required to adopt REDD+ strategies (Luttrell et al., 2012). When current governance cannot escape the influence of past political practices, it creates a situation called "path-dependency" (Pierson, 2000).

This paper, therefore, will primarily draw on the concept of "path-dependency" of forest governance that might block the transformational process in the REDD+ framework in Indonesia. Political power and economic interests have influenced the path-dependency of forest governance in Indonesia. An explanation of path dependency and political economy is presented in sections 2 and 3. This paper employs a political economy lens in identifying path-dependency in order to understanding the transformational change. The political economy approach, introduced by the Center for International Forestry Research (CIFOR), is intended to analyze the complexity of REDD+ around the world since most developing countries have to deal with the political and economic aspects in order to reduce deforestation (Angelsen et al., 2012).

Using a political economy approach, this paper presents a historical perspective of forest governance in Indonesia to identify the path-dependency that has been a part of rule in past government regimes and continues today. Then, this paper then presents the challenge in implementing REDD+ in Indonesia impacted by the path-dependency.

\subsection{Purpose of paper}

In general, the main purpose of this paper is to scrutinize the potential barriers of transformational change especially in Indonesia forest policy in order to achieve the success of REDD+ implementation in Indonesia. Specific objectives are to

1. Assess the importance of transformational change and its key feature, called "path-dependency" that might inhibit or enable the change,

2. Examine the implication of "path-dependency" in implementing REDD+ in Indonesia, 
3. Provide a descriptive analysis of "path-dependency" of forest governance and its impact to the development of REDD+ in Indonesia.

\subsection{Overview}

This paper consists of seven sections. First, an introduction of this paper including the problem statement, topic, purposes and outline of the paper is presented in section 1. A literature review about the progress of REDD+, the importance of transformational change, and the barriers to attaining the success of REDD+ in Indonesia as the main topic of this study are explored in section 2. An explanation of a political economy approach to analyze the substantial factors that might hinder transformational change and presents the research approach is explained in section 3. A historical overview of forest governance in Indonesia is explored in section 4. An analysis of the path-dependency of forest governance system in Indonesia as a key feature that could enable or block changes is presented in section 5 . Finally, the finding of this study and further recommendations such policies about forest governance policy in the framework of REDD+ that could be topics for future research are summarized in section 6 .

\section{Literature Review}

Analyzing path dependency in forest governance in Indonesia is critical in order to realize the transformational change necessary for achieving the success of REDD+ in Indonesia. Many experts have conducted several similar studies about path dependency, and the relationship of path dependency and transformational change. In this section, various literatures related to path dependency and REDD+ are explored. First, the theoretical framework of path dependency is presented in this section with regard to provide a general overview of the relationship between the concept of path dependency and the idea of transformational change. Afterwards, the nexus between transformational change and REDD+ will be described in the rest of this section by presenting literature about the evolution of REDD+'s research and explaining the importance of transformational change to implement REDD+.

\subsection{Path dependency}

Research examining the importance of path dependence and culture for institutions and developments tells us that "history matters." First introduced by North (1990), the notion of institutional "path dependence" has achieved increasing attention among those interested in the connection between institutions and economic growth. Path dependence emphasizes the increasing returns to institutions, which tend to "lock in" particular institutional arrangements that have emerged in various places for unique historical reasons (Boettke, et al., 2008).

By emphasizing the significance of institutions and institutional change in the development and performance of economies, North (1990) challenged neoclassical economics and set the foundation for a comprehensive neo-institutional literature as the present and the future are connected by the continuity of institutions. Through this notion, North (1990) introduced a strong historical dimension to economics and the social sciences, but he integrated historically through his adoption of the concept of path dependence. The concept that historical development can follow specific "path," and that it can even be subject to some 
sort of "dependence." The concept of path dependence is small, early change - deliberate or not - that can have great implications at much later stages, and that certain courses of development, once established, are almost impossible to reverse (North, 1990).

The concept of path dependence was originally used to describe technological change - how the initial choice of technologies limits future options and innovations (Rosenberg, 1994). Path dependence theory serves as a counter to those forms of economic theory which posit that interactions between economically rational actors will lead to efficient outcomes (North, 1990; Pierson, 2000) and provides explanations of the widely observed phenomenon of persisting suboptimal and inefficient patterns of behavior. The theory of path dependence could identify the sources of persistent ineffective institutions.

The studies about path dependency have extended in various aspects at multiple levels from large to small level. Verge and Durand (2010) argued that previous events have determined the present behavior both at the institution level and at the individual level. In other words, path dependency might occur within every organization and each of the individual members of the organization may participate in the path dependency based on past circumstances. In terms of the property rights, path dependency also influences the way in which an institution or individual tends to claim their rights, and that these are affected by particular conditions called "contingency and self-reinforcement" (Vergne \& Durand, 2010). Moreover, contingency and self-reinforcement enable the organization and the members to be locked in under the initial conditions (Vergne \& Durand, 2010).

The theory of path dependency is also associated with "ownership and governance" (Bebchuk \& Roe, 1999). According to Bebchuk and Roe (1999), there are two types of path dependency related to property rights and governance: structure driven and rule driven. According to the authors, structure driven path dependency is determined by two conditions: (1) "sunk adaptive costs, complementarities, network externalities, endowment effects, and multiple optima," and (2) "persistence power." Meanwhile, the rule driven type is influenced by (1) "the initial ownership patterns," and (2) "a country's initial pattern of corporate ownership structures” (Bebchuk \& Roe, 1999).

A path dependence approach has also been applied to natural resources management studies such as in forest policy in Brazil (Mueller \& Alston, 2007), institutional change of forest governance in Russia (Ulybina, 2010), and common pool resources management (Heinmiller, 2009). A study by Mueller and Alston (2007) highlighted "how path dependent nature of the legislation interacted with the changing de facto impact of the law" that is not in conjunction with de jure legislation in designing forest policy. This means that path dependency has affected the distinctions of de facto and de jure law in managing the forest resources.

In addition, Ulybina (2010) conducted a study about path dependency as a limitation to reform in forest governance in Russia. According to this study, the legacy of the Soviet rule has influenced the degree to which the state bureaucracy governs the forests (Ulybina, 2010). Particular weak governance practices such as corruption and counterfeiting legal documents, has also affected the relationship among forestry related actors (Ulybina, 2010).

Another study related to the impact of path dependency on natural resources management was carried out by Heinmiller (2009), who examined the role of path 
dependency in common pools management in the Murray-Darling Basin of Australia, the Colorado Basin of the US and the Saskatchewan-Nelson Basin of Canada. In this study, the author noted that "institutions become path dependent and constrain future choice sets when they provide "positive feedback" to the actors subject to them" (Heinmiller, 2009). Positive feedbacks are investments and adaptations that has been made by the actors for strengthening the institution and that might hinder institutional change (Heinmiller, 2009).

The importance of positive feedbacks enables one to explore the persistence of institutions in maintaining their power in managing resources and to investigate the resistance of institutions to adopt a particular new idea or innovation (Heinmiller, 2009). When these conditions are repeated over time, then it becomes a path, and the preference of institutions to choose the existing decision is called dependent (Pierson, 2000). Therefore, it is important to identify positive feedbacks that could determine whether the institutions are path dependent or not. In doing so, Heinmiller (2009) applied four elements of positive feedbacks in order to explain path dependency within institution. Those elements are "the entrenchment of vested interests, the onset of network effects, the investment of sunk costs, and the creation of formal or informal contracts" (Heinmiller, 2009).

All above several literature on path dependency describe that past events might influence path dependency in an institution. Some analysts also argue that identifying path dependency could be investigated by applying a historical approach (Bebchuk \& Roe, 1999; North, 1990; Pierson, 2000; Vergne \& Durand, 2010). Particularly in natural resources management, Heinmiller (2009) analyzed whether an institution is path dependent using the positive feedback approach. The fact that the main purpose of my research is to identify the path dependency within the Ministry of Forestry, an historical approach and Heinmiller's (2009) framework are applied to examine path dependency in forest governance in the context of political economy. The detailed method for identifying four positive feedbacks will be discussed in section research method (section 3).

2.2 REDD+: from reducing emissions to transformational change

REDD+ (Reducing Emission from Deforestation and forest Degradation Plus) provides an incentive to developing countries for reducing emission from deforestation (RED) in order to mitigate climate change. This concept was proposed by a group of forested developing countries led by Papua New Guinea and Costa Rica in 2005 (Lu \& Liu, 2012). Then, REDD+ was discussed at the $13^{\text {th }}$ Conference of Parties (COP 13) under United Nations Framework Convention on Climate Change in Bali in 2007 and became important on the international agenda on climate change (Pistorius, 2012). The negotiation of REDD+, which had the potential to replace Kyoto Protocol after 2012, was always a priority at the COP agenda every year until the last COP 17 in Durban, South Africa.

The conceptual framework for REDD+ is that industrialized countries will pay developing countries to curtail deforestation and forest degradation. Under the Kyoto Protocol, industrialized countries are called annex 1 countries. The financial incentive from annex I countries will be delivered based on the reporting that forested developing countries have dealt with deforestation. Of course, opportunity costs are incurred when preserving forests, as opposed to converting them to other land uses. Agriculture expansion, plantations for biofuel (e.g. palm oil), and infrastructure development (e.g. road building and mining), contribute more to deforestation than does logging (Kanninen et al., 2007). In 
general, tropical deforestation increases due to an expanding demand for land, not for timber. Countries, moreover, might not only have fewer financial opportunities from land use change, but they may also incur social, economic and political costs associated with REDD+ (Venter \& Koh, 2012). These political economy aspects contribute to the complexity of forest governance in many forested developing countries. Weak forest governance systems consist of inefficient forest regulation, weak law enforcement capacity and perverse incentives (Kanninen et al., 2007). Such conditions do not generally engender forest conservation, but instead reward actors able to exploit governance failures to gain political or economic advantages. Strengthening regulatory frameworks and creating appropriate incentive structures in these situations are difficult precisely because of the political economy currently favoring unsustainable resources exploitation.

Many analysts argue that forest governance is the most significant driver of tropical deforestation (Seymour \& Forwand, 2010). An ambitious idea for addressing governance problems has changed the scope of REDD+ from an only-reducing-emissions project to an effort to provide benefits to developing countries when they are able to reduce deforestation and conserve forests. The reduction of forest emissions and protection of forest resources, however, will have to be supported by a diverse set of policies that address the drivers of deforestation. Angelsen and others (2012), moreover, argued that REDD+ requires transformational change of the forest sector to realize the potential of reducing emission to mitigate climate change. The transformational change can be defined as changing the policy framework from one that stimulates deforestation to one that promotes preserving the forest and sustainable use (Angelsen et al., 2012).

Decentralization and democratization have proven inadequate for addressing the direct drivers and underlying causes of deforestation and forest degradation (Institute of Southeast Asian Studies, 2005). National-level forest governance regimes in tropical countries, such as Indonesia, date from the colonial era and privilege the role of the state in forest management (Seymour \& Forwand, 2010). For example, the Dutch colonial legacy regarding forest management that was adopted and enforced during Suharto's era has hindered the transformational change needed to address deforestation in Indonesia.

\section{Research Approach and Method}

This section outlines the approach and the method used to analyze path dependency. First, the conceptual framework of the political economy perspective to investigate the research topic is described. Second, several studies that use the political economy lens are explored. Third, the research approach, including the historical approach and Heninmiller's (2009) framework, and research techniques are presented.

\subsection{Conceptual framework of political economy perspective}

To investigate the necessary transformational changes of forest governance, due to implementing REDD+, this paper applies a political economy approach that is relevant to understanding the reform process. According to Adam and Dercon (2009), the political economy approach can be applied to examine the formation of institutional structures and the influence of governments and citizens in political and economic choices (Adam \& Dercon, 2009). An understanding of different interests among actors can also be identified by an 
political economy approach - defined as a method to perceive a change in the relationship between political life and the nonpolitical activities to satisfy the private wants (Caporaso, 1992).

World Bank (2008) defines political economy as an "analysis that studies the linkages between politics and economics, drawing on theories of economics, law, political and social sciences" (World Bank, 2008). The political economy approach is particularly useful for scholars to help understand the interest of different groups, both society and political elites and to identify the alternative policy outcomes that may encourage or hinder development (DFID, 2009). This definition implies that politics is related to contesting and bargaining between interest groups with competing claims over power and resources; and economics can generate wealth and influence the policy making process.

Currently, many international development agencies, such as World Bank, United States Agency for International Development (USAID), United Nations Development Program (UNDP), and Department for International Development (DFID), apply the political economy approach to help developing countries in reforming their governance systems. The political economy lens allows researchers to broaden their perspective in addressing such problems related to institution and change (World Bank, 2008). In the context of forest policy reform, applying the political economy approach is also relevant for investigating the reform process in forest governance, especially in the developing countries under democratization and decentralization era such as Indonesia (Brockhaus et al., 2012). Moreover, Luttrell and others (2012) suggested that using the political economy perspective permits one to understand the process of transformational change in the context of the implementation of REDD+.

As mentioned in section 2, the success of REDD+ in Indonesia requires transformational change since the main driver of deforestation in Indonesia is related to institutional problems, such as corruption and cronyism, and economic growth target. Moreover, the complexity of the political condition in Indonesia under democratization and decentralization era, which will be discussed in section 4, might undermine the reform process. Therefore, it is important to understand the political economy perspective in order to investigate the reform process of forest policy and to analyze path dependency as an obstacle for transformational change.

\subsection{Research method}

The main objective of this paper is to analyze key factors of path dependency that might block or enable the transformational change process, and its implication to implement REDD+ in Indonesia. In order to determine the path-dependency in Indonesia's political economy, this paper employs historical analysis of forest governance in Indonesia from the colonial era to the current regime. This research method allows the study to analyze policy changes associated with the political and economic paradigms that affect forest policy reform in Indonesia. This method also helps to show the complexity and the consequences of forest governance reform in Indonesia.

In doing so, this study explores three main eras in which there were significant changes in forest governance in Indonesia. These eras are:

1. Colonial era under Dutch's administration (late 1800's - 1942), 
2. Post-independence era under President Sukarno and Suharto (1945 - 1998),

3. Reform and decentralization era (1998 - current time).

The data set and information utilized to analyze the path-dependency is comprised of several sources. Documentary information was used to identify relevant official government public policy statements and actions. Information was gathered from secondary sources including Law No. 41/1999, several reports and working paper from CIFOR. The study also relies on secondary information from reputable journals, magazines, new papers, and online discussion. Selected recent readings from reputable academic journal are used such as Forest Policy and Economics, Environmental Policy, and Ecological Economics.

Exploring the historical overview of forest governance in Indonesia allows understanding how decisions related to forest sector were made. The historical decisionmaking process might generate positive feedback from the institution that resists change or reform of the current decision-making process. As mentioned in section 2.1, these positive feedbacks could can persist for long period and may become entrenched within the institution, which is one indication of path dependency. Simply put, it can be said that the institution is path dependent if it provides positive feedbacks for the actors to resist change. Heinmiller (2009) made valuable distinctions of positive feedbacks that consist of (1) vested interests - particular interests established in multi-level of institutions, (2) network effects - mutual benefits from institutions and their allies either by legal or illegal actions, (3) sunk costs - significant amount of resources allocated to maintain power, and (4) formal/informal contracts - agreement between institution and other actors in managing natural resources.

Applying Heninmiller's (2009) framework, this paper mainly focuses on investigating those four distinctions of positive feedback within the Ministry of Forestry, a key actor in governing the Indonesia's tropical forests. In this paper, those positive feedbacks are:

1. The interest of Indonesian's multi-level governments in managing the forests,

2. The relationship between the government agency and private companies or other stakeholders,

3. The sunk costs invested in forest management and REDD+, and

4. The nature of contractual (agreement) between state and society in managing the forests.

After identifying the path dependency, this study explores the implication of the pathdependency to REDD+ in Indonesia, and investigates the potential for positive change to emerge under the REDD+ mechanism in Indonesia.

\section{Historical Overview of Forest Governance in Indonesia}

The history of forest governance in Indonesia is complex, especially from the colonial era (late 1800's) until the democratization era (present). This section is divided into three parts in order to explore a historical overview of forest governance under different regimes in Indonesia. First, the influence of the Dutch as the colonialist in creating the concept of state forest is presented. Second, the post-independence forest governance under Presidents 
Sukarno and Suharto era is explored. Third, the complexity of forest governance under democratization and decentralization era, which is still underway, is described.

4.1 Colonial era under Dutch administration (late 1800’s - 1942)

Path-dependency of forest governance in Indonesia is closely associated with the role of colonial management of the forest before Indonesia became independent. Javan forest policy has been replicated throughout Indonesia and in other parts of the forested tropics due to the assumption that the Javan forest management is more systematic and financially beneficial, without understanding the social or environmental history or the political implications of this form (McCarthy, 2000; Peluso, 1992). Javan forest management is characterized by monoculture forest plantations and the exclusion of rural communities from state forest land, and has been imitated in other forested regions after all of the primary forest have been cut, both by domestic and foreign firms (Barr et al., 2006; McCarthy, 2000; Peluso, 1992).

The Dutch, Indonesian colonialists of the $19^{\text {th }}$ century, successfully influenced and brought a forest governance system to Indonesia, but the Dutch never surveyed village boundaries in Java or other parts of Indonesian forested land (Peluso, 1992). Peluso (1992) also mentioned the current notion that collective territorial rights are state owned and not held by households. Currently, the land disputes between the state and rural communities remain unsolved since there is unclear policy for recognizing rural forest communities. Moreover, in establishing legal jurisdiction, the Dutch also ignored the pre-colonial local practices and power relations. This is especially evident in identifying the colonial authorities' power over natural resources and their view of the local communities as mere labor and with property rights in forest products rather than in the land itself (Peluso \& Vandergeest, 2001).

Colonial authorities, therefore, created "states forest" in which the state has power to govern the resources and to exclude the people living in the forests. The notion of "states forest" remained strongly challenged during and after the colonial period, both within the states' bureaucracies and by their intended subjects (Peluso, 1992). For instance, the state forest in Java is currently managed by a state-owned enterprise, called "Perhutani." Even though the Perhutani has initiated collaboration in forest management with communities, this mechanism still does not give a significant benefit to rural communities, and cannot solve the land tenure problem (Peluso, 2011).

4.2 Post-independence era under Sukarno and Suharto (1945 - 1998)

In post-independence, during President Sukarno's regime, the Indonesian government adopted regulations and policies to reinforce state forest power over the entire forest state in Java (Barr et al., 2006). The policy makers viewed Java's forest management as the best forest management, such that they replicated this model to other forested regions in Indonesia. Most tropical forests in Indonesia were managed by military commanders since Indonesia had no experts or professionals in forest management (Barr et al., 2006). This condition parallels with Olsen's argument in Martinussen's book "where the national bourgeoisie and other capitalist classes are weak, the civil and military bureaucracies may fill the power vacuum and achieve significant influence over the policies of state" (Martinussen, 1997). At the beginning of President Suharto's new order era in 1966, the authority of the central government to control forest resources both in Java and the entire 
tropical forest regions increased sharply (Barr et al., 2006). The government released forestry laws to legitimize occupying the tropical forest in Indonesia. The policy makers clearly designed a forest state to provide spatial and legal certainty in order to dominate the area's status as state-controlled forestland (Peluso, 1992). Consequently, the Ministry of Forestry, assigned as the forest administrative agency, governs more than half of Indonesian land.

Legitimized by Indonesian Forestry Law, the Ministry of Forestry has powerful authority to distribute, manage and control forestland, as public land; the Ministry of Forestry is the only government agency permitting forest concessions. This authority has led to a close relationship between the Ministry and businessmen. While the Ministry of Forestry has authority for controlling forest concessions, the businessmen need high returns (profit) from forest exploitation. As a result, the businessmen usually gave "wild money" to the forestry officials for allowing them to harvest the forests in excess of the normal quota (Purwanto, 2005). Moreover, as there was no transparency in releasing the forest concessions and the annual harvest permitted, the forest industry in Indonesia was managed by a few elites, especially those who had connections with President Suharto. President Suharto and his allies unsustainably exploited the forest concessions in order to attain high profit (Barr et al., 2010).

Winters (2011) described the oligarchic system in Indonesia that was introduced and institutionalized during the Suharto era. According to him, the actors within this system are known as oligarchs "who command and control massive concentrations of material resources that can be deployed to defend or enhance their personal wealth and exclusive social position" (Winters, 2011). He goes on to say that Suharto was a Sultanistic Oligarch due to his authoritarian and dictatorship style in governing the country for more than three decades (Winters, 2011). During the Suharto era, many issues in the forest industry noticeably show how Suharto and his political allies exclusively dominated the concessions to maintain the Suharto regime. For instance, Bob Hasan was appointed as Minister of Trade and Industry to monopolize and to conquer the forest concession and its industries, which gave him the nickname "raja hutan" (the king of the forests) (Hapsari, 2011). Consequently, Bob Hasan and Suharto's allies expanded their unsustainable forest exploitation unceasingly, which yielded massive deforestation during that era.

4.3 Reform and decentralization era (1998 - now)

Although President Suharto lost power and a democracy was promoted in 1998, the oligarchic system continued to thrive. The Indonesian oligarchs become "more freelancing" - occupying new posts as political elites and politico-bureaucrats both in central and local levels (Winters, 2011). For example, the Corruption Eradication Commission (KPK), in 2012, succeeded in condemning two former district leaders - convicted for establishing an illegal permit for converting forest area to agriculture plantation in Riau (suarapembaruan.com, 2012). Moreover, in 2008, the corruption scandal of a former governor for South Sumatera, who was also involved with six Members of Parliament and businessmen, is another example of oligarchic practices involving the forest governance in provincial and district level (Widhi, 2012). 
After 32 years of President Suharto's regime, the economic and political crises of 1997-1998 stimulated Indonesia to transform its forest policy to give the provinces and districts considerably more autonomy in managing natural resources and to allow them to retain the bulk of the tax revenue (Resosudarmo, 2004). However, as the decentralization process in the forestry sector moved far more rapidly than they had anticipated, policymakers at the Ministry of Forestry soon attempted to recentralize forest administration by structuring and proposing Law 41/1999 to the parliament (Barr et al., 2006). This regulation reaffirmed the Ministry's dominant role in administering the nation's forest resources. The outcome in terms of forest management has been disastrous: subsequent attempts to recentralize - notably the rights to allocate concessions - have not succeeded, leading to conflicting regulations, and confusing situations that many players exploit (McCarthy, 2000).

Moreover, along with decentralization policy reform, the Ministry of Forestry has transferred some of their authority in managing forests to local governments thereby increasing the local government's power to administer the forests. Currently, the local governments have an obligation to issue location permits and plantation licenses even though the allocated land is still authorized by the Ministry of Forestry (Barr et al., 2006). The right in managing forest areas - legalized by a decentralization law - encourages the district leader to accelerate generation of economic revenue by encouraging outside investors to cultivate the resources for the sake of achieving the development agenda.

As Indonesia is in transition, from developing to developed nation, its economic growth still heavily depends on natural resource sectors. Businessmen from these sectors are among the wealthiest people in Indonesia 16 of the 21 billionaires made their fortunes in these sectors (Forbes Indonesia, 2010). Barr and others (2010) also describe that there is a close relationship among businessmen, politicians and bureaucrats in the forestry arena. Private interests heavily influence the decision-making process because they, as lobbyists, back up the politicians who have a desire of becoming local leaders or parliament members. Private interests fund their election campaigns, and they also finance pro-development organizations such as World Growth to conduct studies underpinning their business (Edwards et al., 2012).

\section{Path-Dependency and Forest Governance in Indonesia}

In this section, four positive feedbacks, as discussed earlier in section 2 and 3 , are investigated in order to illustrate the concept of path dependence within the Ministry of Forestry. This is examined with regard (1) to maintaining control of forest resources and (2) to being a leading institution for REDD+. The first positive feedback that is explored in this section is the interest of multi-level state institution in managing the forests. Then, the relationship among actors related to forest management is presented as the second positive feedback. The third feedback, the sunk costs invested by the Ministry of Forestry, is described afterward. Fourth, the nexus between state and society in utilizing the forests is presented. 
5.1 The interest of multi-level Indonesian governments in managing the forests

The success of the forest sector in contributing to economic development during Suharto's era has vested certain interests in utilizing the forest resources as an economic source to Indonesia's government agencies. It is commonly claimed that a significant role of forests in national development in 1980's - 1990's successfully supported national economic growth and massive job creation opportunities (Barr et al., 2010; Gellert, 2005). During Suharto's era, the central government bureaucracy set up a national forest policy as a part of a 25-year long-term development plan or Garis Besar Haluan Negara (GBHN), designed by Ministry of National Development Planning (Bappenas). The Bappenas then translated the GBHN into a 5-year midterm development plan or Rencana Pembangunan Lima Tahun (Repelita). Under this authoritarian system, this national development plan had to be implemented by other government agencies including the Ministry of Forestry and local governments. Along with other sectors, Indonesia's tropical forest was seen as a potential renewable resource that could generate crucial national income and achieve other national development goals. During 1993 - 1995, the forest products sector generated around US $\$ 6$ billion to Gross National Product (GNP) per year, the second biggest economic sector, after oil and gas (Palo \& Vanhanen, 2000).

The tremendous achievement from forests resources established a paradigm of development in Indonesia that relies heavily on land-based sectors, until recent times. Consequently, the central government also created politically powerful "vested interests" to exploit forests and other natural resources within various government agencies either central or local in Indonesia. When decentralization occurs in Indonesia, forest exploitation by logging activities, both legal and illegal, has shifted from national entities to local actors (Casson \& Obidzinski, 2002). The vested interests behind forest governance have also expanded the link between corruption and illegal logging in local governments (Casson \& Obidzinski, 2002).

Currently, Indonesia's forests are not only useful sources of timber, but they also fuel other industries, such as agriculture, mining and hard public infrastructures (road, bridge, airport, housing, industrial complex, canals etc.). Forest sector activities are most important in converting land to other land-uses such as oil palm, coal exploitation and new road construction, while the economic value of forest products such as timber, plywood and pulp, and has decreased both in the domestic and the global market. However, policy-makers in Indonesia have pushed for allocating land based on economic considerations rather than enforcing sustainable natural resources management and social equity. A study conducted by Brockhaus and others (2012) highlighted that the policies and politics surrounding land use planning are enacted to support economic growth and to meet the global demand for energy and food. As a result, the policies promoted forest exploitation.

In summary, the vested interests for using the forest resources to accelerate economic growth have become entrenched in multiple government agencies in Indonesia since Suharto's era. Thus this indicates that a positive feedback to path dependency particularly in the Ministry of Forestry as the main agency which administers the forests area in Indonesia. The weak governance system has worsened the situation, and the vested interests converted natural forests to their economic benefit. Therefore, if this positive feedback is to be disrupted, appropriate compensation from REDD+ to protect the forests and spread benefits 
is needed. Improved law enforcement is a prerequisite for the success of REDD+ in Indonesia.

5.2 The relationship between the government agencies and privates businesses

As discussed in section 4, there is a close relation between political and bureaucratic elites in the land-based natural resource sector. In the context of political tradition, the private businesses forest sector has heavily influenced the decision-making process through informal networking. Thus it seems that "the line between the state and the private sector is blurred" (Luttrell et al., 2012). Along with the vested interest behind economic development policy, a significant role of businesses in the forest sector has created network effects between state and private entities.

The longstanding economic model under Suharto's era has created a patron-client relationship between the investor and the President's allies. When Indonesia's economic model has become increasingly open to market-based competition, the patron-client relationship still persists. Moreover, private businesses often form partnerships with political elites in order to support their interests (Gellert, 2005). This informal network does not only occur at the national level, but it also quickly spreads from central to local governments. The businessmen, through politically powerful individuals, try to gain favor with the local politicians for the sake of maintaining their business operation (McCarthy, 2002).

In the context of REDD+, these network effects might threaten the implementation of REDD+ projects. For example, the Rimba Raya REDD+ project illustrates the influence of this web. This forest carbon project was designed to avoid planned deforestation from oil palm expansion in Central Kalimantan. Though Rimba Raya started in 2009, the Ministry of Forestry did not approve and legalize this forest carbon project until 2012. The permit of a giant palm-oil company, which overlaps with the REDD+ project area in Central Kalimantan, had created a legal quandary (Banyan, 2012). The oil palm investor lobbied Ministry of Forestry officials to suspend the forest carbon project through their informal networking.

The nature of the informal network between state and private individuals has mutually benefitted them; however, it raises questions of social equality, as few Indonesian citizens profit from this relationship. These network effects that have been created over a long period provide one example of a positive feedback that contributes to the Ministry's path dependency. Thus, the closed relationship with private businessmen might undermine the government reform process that is essential to REDD+. However, if the Ministry promoted the notion of REDD+ to private businessmen through their network so that they might invest in the REDD+ program, this relationship could support the success of REDD+ in Indonesia. As the role of private companies is important for long-term investment, this example of path dependency within the Ministry of Forestry to hold the power in managing forests could likely be directed for supporting the REDD+ program.

5.3 The nature of relationship between state and society in managing the forests

The last positive feedback to determine whether the Ministry of Forestry is path dependent in monopolizing the forests resources is identified through the relationship between the Ministry and society in utilizing the forest resources. The significant roles of 
the Dutch and the authoritarian regime during Suharto's era, as discussed in section 4, have contributed to the link between state and society in Indonesia. Indonesian tropical forests have become a public good and legalized under the Indonesian Institution. According to the Indonesian Constitution, all resources, including forest resources, needed by citizens must be owned and controlled by the state on behalf of Indonesian society in order to increase social welfare. In other words, the government, on behalf of the people, claims all Indonesian forest area, whether or not the land is forested.

The Ministry of Forestry, unfortunately, has misused its right to claim forested area as state forest particularly in allocating the forestland to concessionaries. Instead of encouraging local communities to utilize the forestland, the officials only promote forest concessions proposed by private businesses (McCarthy, 2000). Vested interests of the bureaucrats and close networks with private businesses have worsened this condition. Moreover, there is no incentive for the officials or the local community to develop community-based forest management, which has discouraged the concept of community forestry. For example, in Malinau, East Kalimantan, forest land-use decisions serve the interest of district officials in income-generating projects, which they justify with narratives about economic development and modernization. The private businessmen also help maintain political capital among the district's entrepreneurs, create job opportunities for communities, and select village leaders who also benefit from the schemes (Wollenberg et al., 2008).

Various analyses found that the relationship between land allocation for private concessionaries has diminished the opportunity for the community to cultivate the forests (McCarthy, 2000; Peluso, 1992). Through their networks in the government agencies, the private businesses attempt to secure and occupy the land for expanding their business on forest and plantations. On the other hand, though local communities do not have land titles due to lack of information, they already use and utilize the lands for their daily livelihoods, either through forest or plantation management. Backed by officials and military troops, the private entities try to secure their concessions by forcing the communities to move out from the concessionaries' land (McCarthy, 2000). When the communities lose their property rights for land management, harvesting on these forests and plantations becomes illegal. Thus, it is commonly accepted that these communities are suspected as "illegal loggers" in their own land. The lack of governance capacity and complicated regulations involved with obtaining a land certificate or permit are the main reasons that the local communities have never acquired property rights from the government. On the other hand, the concessionaries are able to claim the forestland easily through lobbying (McCarthy, 2000).

With regard to the implementation of REDD+, excluding communities from forests will undermine the success of REDD+ in two ways. First, it ignores the problem of deforestation related to land tenure, as local communities are the main actors in direct contact with the forest resources. A study carried out by Huma, the Indonesian Civil Society Organizations, found that there are at least 119 unresolved conflicts between communities and private sectors and more than 30,000 villages located inside the forests area in which the legal status of those villages remains unclear (Saturi, 2013). Since the problem is at the local level, an effective effort to address deforestation must involve the local actors - the communities - in using and managing the forest resources. Promoting land ownership and 
property rights for communities is a necessary feature of REDD+, in order to protect local community livelihoods. The role of officials and non-government organizations in granting these rights is very critical. In addition, the REDD+ fund could be used to support the communities in applying sustainable forest management. A main question related to REDD+, which remains unclear, is how much the benefit sharing from REDD+ will help the officials and non-government organizations in to grant property rights remains unclear.

Second, barring communities from using the forests might also result in potential problems of issuing carbon rights, particularly if emissions from reducing deforestation can be credited. A critical issue in the current REDD+ debate is whether forest ownership determines carbon rights. In the context of land ownership in Indonesia, as most forestland in Indonesia is owned by the government, who will get credit from reducing deforestation remains an unanswered question. Even though the fund from REDD+ can be distributed based on agreements between the state and communities, lack of transparency and corruption, regarding previous financial management related to forest revenue, might hinder the distribution of REDD+ incentives (Barr et al., 2010). If the national government is to govern REDD+ projects, it must ensure that the funds will be distributed equitably for all actors related to forest management, both state and society (Karsenty \& Ongolo, 2012).

\section{Discussion and Conclusion}

An understanding of the path dependency of forest governance using a political economy context is important to realize the transformational change required for REDD+ to succeed in Indonesia. Path dependency within the institution, which has responsibilities to govern, administer, and manage the forests in Indonesia, is associated with the influence of the colonial legacy and the past authoritarian regime. The nature of state forest, designed by the colonialist and adopted by the Indonesian forest governance system, has resulted in the exclusion of the communities from the forest areas. In addition, the authoritarian regime during Suharto's era misused its authority to manage the forestland for more than three decades (McCarthy, 2000). A key feature of this regime is characterized by a weak governance system that eventually caused high rates of deforestation. Ironically, this particular governance system persists and even thrives under the democratization and decentralization era (Ash Institute for Democratic Governance and Innovation, 2011). Even though the internal and external communities have insisted on reforming the forest governance system, the institution resists change due to path dependency.

With regard to determining whether an institution is path dependent or not, in this paper, the positive feedbacks into this institution are described. Once identified these positive feedbacks can be analyzed using a historical approach (Heinmiller, 2009). By applying a historical perspective throughout this paper, I found that there are four positive feedbacks that indicate path dependency in forest governance in Indonesia. First, vested interests to exploit and to convert the forests to other land uses for the sake of increasing economic growth are still entrenched within the Indonesian government. Second, network effects that were built by political or bureaucratic elites and private businessmen for allocating the forests land under the previous regime, have impeded an effort to reduce deforestation. Third, a close relationship between the officials and the private businessmen has undermined the participation of society in utilizing the forests. The tremendous cost that has been 
invested by the Ministry of Forestry to develop REDD+ is also an important positive feedback that contributes to path dependency.

All of these positive feedbacks indicate that there is a path dependency within the government agency, particularly within the Ministry of Forestry in governing the forests. The path dependency of forest governance has also affected the reform process of forest governance under the framework of REDD+ in Indonesia. The establishment of the Indonesian REDD+ National Strategy is not necessarily sufficient to address the path dependency. A lack of clarity in the legal aspects of this strategy might not contribute to changing the "business as usual" governance system. Despite Presidential support to implement the strategy, additional political support is also important since Indonesia's political system currently requires an endorsement from Parliament to change such a governance system.

In addition, the same positive feedbacks that show an institution, such as the Ministry of Forestry, to be path-dependent created complexity in the REDD+ debate in Indonesia, particularly when designing the REDD+ Agency in Indonesia in 2011. The notion of the Indonesian REDD+ Agency is primarily to administer REDD+'s projects, to conserve the forests and livelihoods, and to manage finances, both from mandatory and voluntary funding. The discourse surrounding the new REDD+ Agency is expected to address the path dependency within the current institution, coordinate various government agencies and other stakeholders, and realize the reform process of forest governance in Indonesia. Previous experience in creating new agencies in other sectors has generated confusion among government agencies, because such new institutions often lack power and authority (Luttrell et al., 2012). Integrating the REDD+ Agency into the current institution might be effective in diminishing the need for future implementation of governance reform and hence reinforcing the status quo. However, this process must be able to be monitored and controlled by the public in order to deal with transparency and accountability issues. Public support could be achieved by creating a space for the public to participate in the implementation of the reform process to guarantee success of the REDD+ in Indonesia.

On the other hand, the idea of REDD+ provides good momentum for Indonesia to break its path dependency. The reaction of the Ministry of Forestry in proposing a different REDD+ Agency suggests that the Ministry of Forestry is concerned with reforming their institution. The establishment of the 2-year moratorium on the issuance of new permits in forests and peatland area is another good example of addressing path dependency in forest governance. As an effort to slowing down deforestation in Indonesia, this policy has generated many positive outcomes. For example, during the moratorium period, several government agencies collaborate to synchronize overlapping maps and land allocation. Moreover, the Government of Indonesia has begun to involve non-state actors by conducting public consultations during the development of the National REDD+ Strategy, in order to impose transparency and participation. These examples above indicate the positive impacts of REDD+ to break path dependency and to realize the transformational change in forest governance in Indonesia.

Based on my descriptive-qualitative analysis and findings, I suggest that path dependency can be a key hindrance or enabler to the reform process of forest governance in order to achieve the success of REDD+ in Indonesia. This paper also highlights that 
understanding path dependency through the political economy context helps to understand the difficulties surrounding the implementation of such a program to protect the forest resources. Particularly for forested developing nations, which may participate in the REDD+ mechanism, weak governance systems are an important factor that might interfere with reducing deforestation. Thus, in order to realize REDD+ in most developing countries, it is crucial to understand institutional legacies from previous regimes that persist in the current governance system.

Realizing the transformational change necessary for REDD+ to succeed is challenging for forested developing countries, most of which are undergoing an economic or political transitional era. Indonesia is also transitioning from an authoritarian to a democratic government. The resulting change in political and social aspects has also impacted the management of forest resources, particularly under the decentralization era. Previous failures of decentralized forest governance might raise concerns within the national REDD+ context on whether or not the provincial level could participate in REDD+. To further my research, therefore, I intend to investigate the institutional transformation in managing the Indonesian forest resources in Indonesia in this transition era to enable the reduction of deforestation and the protection of the local livelihoods and their rights.

\section{References}

Adam, C., \& Dercon, S. (2009). The political economy of development: an assessment. Oxford Review of Economic Policy, 25(2), 173-189. doi:10.1093/oxrep/grp020

Angelsen, A., Brocckhaus, M., Sunderlin, W. D., \& Verchot, L. V. (Eds.). (2012). Analysing REDD+: challenges and choices. Bogor, Indonesia: Center for International Forestry Research (CIFOR).

Ash Institute for Democratic Governance and Innovation. (2011). From reformasi to institutional transformation: a strategic assessment of Indonesia's prospects for growth, equity, and democratic governance. Cambridge, Mass., U.S: Harvard Kennedy School, Ash Center for Democratic Governance and Innovation.

Banyan. (2012). Palming off. The Economist. Retrieved December 22, 2012, from http://www.economist.com/blogs/banyan/2012/12/indonesias-forests-and-redd

Barr, C., Dermawan, A., Purnomo, H., \& Komarudin, H. (2010). Financial governance and Indonesia's Reforestation Fund during the Soeharto and post-Soeharto periods, 19892009: a political economic analysis of lessons for REDD+ (Occasional paper No. 52). Bogor, Indonesia: Center for International Forestry Research (CIFOR).

Barr, C., Resosudarmo, D. P., Dermawan, A., \& McCarthy. (2006). Decentralization of forest administration in Indonesia: Implication for forest sustainability, economic development and community livelihoods. Bogor, Indonesia: Center for International Forestry Research (CIFOR).

Bebchuk, L. A., \& Roe, M. J. (1999). A theory of path dependence in corporate ownership and governance. Stanford Law Review, 52(1), 127-170. doi:10.2307/1229459 
Boettke, P. J., Coyne, C. J., \& Leeson, P. T. (2008). Institutional stickiness and the new development economics. American Journal of Economics and Sociology, 67(2), 331358.

Brockhaus, M., Obidzinski, K., Dermawan, A., Laumonier, Y., \& Luttrell, C. (2012). An overview of forest and land allocation policies in Indonesia: Is the current framework sufficient to meet the needs of REDD+? Forest Policy and Economics, 18(0), 30-37. doi:10.1016/j.forpol.2011.09.004

Bünte, M., \& Ufen, A. (Eds.). (2009). Democratization in post-Suharto Indonesia. London ; New York: Routledge.

Caldecott, J., Indrawan, M., Rinne, P., \& Halonen, M. (2011). Indonesia-Norway REDD+ Partnership: first evaluation of deliverables. Oslo: Gaia Consulting.

Caporaso, J. A. (1992). Theories of political economy. New York: Cambridge University Press.

Casson, A., \& Obidzinski, K. (2002). From new order to regional autonomy: shifting dynamics of "Illegal" logging in Kalimantan, Indonesia. World Development, 30(12), 2133-2 151. doi:10.1016/S0305-750X(02)00125-O

Crouch, C., \& Farrell, H. (2004). Breaking the path of institutional development? alternatives to the new determinism. Rationality and Society, 16(1), 5-43. doi: $10.1177 / 1043463104039874$

DFID. (2009). Political economy analysis: How to note (A Practice Paper). London: Department for International Development.

Edwards, D. P., Koh, L. P., \& Laurance, W. F. (2012). Indonesia’s REDD+ pact: Saving imperilled forests or business as usual? Biological Conservation, 151(1), 41-44. doi:10.1016/j.biocon.2011.10.028

Forbes Indonesia. (2010). Indonesia’s Wealthiest. Retrieved August 10, 2012 from LexisNexis Universe

Gellert, P. K. (2005). The shifting natures of "Development": Growth, crisis, and recovery in Indonesia's forests. World Development, 33(8), 1345-1364. doi:10.1016/j.worlddev.2005.03.004

Hapsari, M. (2011). The political economy of forest governance in post-Suharto Indonesia. Retrieved December 27, 2012 from http://www2.gsid.nagoyau.ac.jp/blog/anda/files/2012/01/3_maharani-hapsari1.pdf

Heinmiller, T. (2009). Path dependency and collective action in common pool governance. International Journal of the Commons, 3(1), 131-147.

Houghton, R. . (2012). Carbon emissions and the drivers of deforestation and forest degradation in the tropics. Current Opinion in Environmental Sustainability, 4(6), 597603. doi: 10.1016/j.cosust.2012.06.006

Institute of Southeast Asian Studies. (2005). The politics and economics of Indonesia's natural resources. (Indonesia Update Conference, Ed.). Singapore: Institute of Southeast Asian Studies. 
Kanninen, M., Murdiyarso, D., Seymour, F., Angelsen, A., \& Wunder, S. (2007). Do trees grow on money?: The implications of deforestation research for policies to promote REDD. Bogor, Indonesia: Center for International Forestry Research (CIFOR).

Karsenty, A., \& Ongolo, S. (2012). Can "fragile states" decide to reduce their deforestation? The inappropriate use of the theory of incentives with respect to the REDD mechanism. Forest Policy and Economics, 18(0), 38-45. doi:10.1016/j.forpol.2011.05.006

Lu, H., \& Liu, G. (2012). A case study of REDD+ challenges in the post-2012 climate regime: The scenarios approach. Natural Resources Forum, 36(3), 192-201. doi: $10.1111 /$ j.1477-8947.2012.01452.x

Luttrell, C., Resosudarmo, I. A. P., Muharrom, E., Brockhaus, M., \& Seymour, F. (2012). The political context of REDD+ in Indonesia: Constituencies for change. Environmental Science \& Policy, (0). doi:10.1016/j.envsci.2012.10.001

Martinussen, J., \& Human Sciences Research Council. (1997). Society, state and market: a guide to competing theoriesof development. London; Atlantic Highlands, N.J. : Halifax,N.S. : Pretoria, South Africa: Zed Books : Fernwood Pub.; HRSC/RGN.

McCarthy, J. (2000). The changing regime: Forest property and reformasi in Indonesia. Development and Change, 31(1), 91-129. doi:10.1111/1467-7660.00148

McCarthy, J. F. (2002). Turning in circles: District governance, illegal logging, and environmental decline in Sumatra, Indonesia. Society \& Natural Resources, 15(10), 867-886. doi:10.1080/08941920290107620

Ministry of Environment. (2010). Indonesia Second National Communication under The United Nations Framework Convention on Climate Change (UNFCCC). Jakarta, Indonesia: Republic of Indonesia.

Ministry of Finance. (2009). Economic and fiscal policy strategies for climate change mitigation in Indonesia. Ministry of Finance, Republic of Indonesia.

Ministry of Forestry. (2012a). Indonesian forest statistic. Jakarta, Indonesia: Ministry of Forestry.

Ministry of Forestry. (2012b). National forestry plan 2011-2030. Jakarta, Indonesia: Republic of Indonesia.

Mueller, B., \& Alston, L. J. (2007). Legal reserve requirements in Brazilian forests: Path dependent evolution of de facto legislation (Anais do XXXV Encontro Nacional de Economia [Proceedings of the 35th Brazilian Economics Meeting] No. 147). ANPEC Associação Nacional dos Centros de Pósgraduação em Economia ¿Brazilian Association of Graduate Programs in Economics]. Retrieved from http://ideas.repec.org/p/anp/en2007/147.html

Murdiyarso, D., Brockhaus, M., Sunderlin, W. D., \& Verchot, L. (2012). Some lessons learned from the first generation of REDD+ activities. Current Opinion in Environmental Sustainability, 4(6), 678-685. doi:10.1016/j.cosust.2012.10.014 
North, D. C. (1990). Institutions, institutional change, and economic performance. Cambridge; New York: Cambridge University Press.

Palo, M., \& Vanhanen, H. (Eds.). (2000). World forests from deforestation to transition? Dordrecht; Boston: Kluwer Academic Publishers.

PEACE. (2007). Indonesia and climate change: Current status and policies. Jakarta, Indonesia: The World Bank and DFID. Retrieved from http://siteresources.worldbank.org/INTINDONESIA/Resources/Environment/ ClimateChange_Full_EN.pdf

Peluso, N. L. (1992). Rich forests, poor people: resource control and resistance in Java. Berkeley: University of California Press.

Peluso, N. L. (2011). Emergent forest and private land regimes in Java. Journal of Peasant Studies, 38(4), 811-836. doi:10.1080/03066150.2011.608285

Peluso, N. L., \& Vandergeest, P. (2001). Genealogies of the political forest and customary rights in Indonesia, Malaysia, and Thailand. The Journal of Asian Studies, 60(3), 761812.

Pierson, P. (2000). Increasing returns, path dependence, and the study of politics. American political science review, 94(2), 251-268.

Pistorius, T. (2012). From RED to REDD+: The evolution of a forest-based mitigation approach for developing countries. Current Opinion in Environmental Sustainability, 4(6), 638-645. doi:10.1016/j.cosust.2012.07.002

Purwanto, S. (2005). Forest resources management and self-governance in regional autonomy Indonesia. In M. Erb, P. Sulistiyanto, \& C. Faucher (Eds.), Regionalism in post-Suharto Indonesia. London; New York: RoutledgeCurzon.

Resosudarmo, I. A. P. (2004). Closer to people and trees: Will decentralisation work for the people and the forests of Indonesia? The European Journal of Development Research, 16(1), 110-132. doi:10.1080/09578810410001688761

Rosenberg, N. (1994). Exploring the black box: technology, economics, and history. Cambridge [England]; New York: Cambridge University Press.

Saturi, S. (2013, February 16). Tersebar di 98 kabupaten, konflik agraria didominasi sektor perkebunan dan kehutanan. Retrieved January 30, 2013 from mongabay.co.id.

Seymour, F., \& Forwand, E. (2010). Governing sustainable forest management in the new climate regime. Wiley Interdisciplinary Reviews: Climate Change, 1(6), 803-810. doi: $10.1002 /$ wcc. 70

Suarapembaruan.com. (2012, November 6). KPK periksa Darmawi terkait dugaan korupsi kehutanan. Jakarta, Indonesia. Retrieved February 1, 2013 from http://www.suarapembaruan.com/home/kpk-periksa-darmawi-terkait-dugaankorupsi-kehutanan/26559

Ulybina, O. (2010). Institutional change in the forest sector: the Russian experience. Retrieved from http://www.dspace.cam.ac.uk/handle/1810/236997 
Venter, O., \& Koh, L. P. (2012). Reducing emissions from deforestation and forest degradation (REDD+): game changer or just another quick fix? Annals of the New York Academy of Sciences, 1249(1), 137-150. doi:10.1111/j.1749-6632.2011.06306.x

Vergne, J.-P., \& Durand, R. (2010). The missing link between the theory and empirics of path dependence: Conceptual clarification, testability issue, and methodological implications. Journal of Management Studies, 47(4), 736-759. doi:10.1111/j.14676486.2009.00913.x

Widhi, N. (2012, February 14). Ini dia kasus-kasus korupsi yang menjerat anggota DPR. $\begin{array}{llll}\text { Retrieved } & \text { February } & 10, & 2013\end{array}$ http://news.detik.com/read/2012/02/14/154228/1842180/10/ini-dia-kasus-kasuskorupsi-yang-menjerat-anggota-dpr

Winters, J. A. (2011). Oligarchy. Cambridge; New York: Cambridge University Press.

Wollenberg, E., Campbell, B., Dounias, E., Gunarso, P., Moeliono, M., \& Sheil, D. (2008). Interactive land use planning in Indonesian rain-forest landscapes: Reconnecting plans to practice. Ecology and Society, 14(1), 35.

World Bank. (2008). The political economy of policy reform: Issues and implications of policy dialogue and development operations. Social Development Department, Environmentally and Socially Sustainable Development Network, Washington DC: World Bank. 